\title{
Teaching Reform of Industrial Automation based on Engineering Education Certification
}

\author{
Xin Ping, Mi Hongtao \\ BeiHua University,Jilin City Longtan Hill Street No. 1, JiLin, China \\ BeiHua University,Jilin City Longtan Hill Street No. 1, JiLin, China \\ 359411897@qq.com, 17207527@qq.com
}

\begin{abstract}
Keywords: Reform in Education, Education certification, Industrial automation engineering practice
\end{abstract}

\begin{abstract}
With the development of education, society and economy, the certification of engineering education has become a necessity. In order to meet the needs of the transformation and upgrading of industries and the promotion of new industry found that engineering education needs to adjust the traditional curriculum content, establish a student-centered education concept, the essences of education quality lies in the ability of the students. All education teaching process and the link should be based on students, teaching organization and methods. Teaching resource allocation should be conducive to the cultivation of the students' ability and quality, all the education teaching activities to efforts in the direction of cultivation standards and achieve goals.
\end{abstract}

\section{In view of the Industrial Automation Engineering Practices to Construct Innovative Reform Measures}

In engineering education CDIO concept design teaching, to cultivate the engineering application ability and life-long learning ability as the main line, with project as the carrier, by means of application of information technology, the research and practice inquiry, inquiry learning. Fig.1 shows the building innovative reform measures.

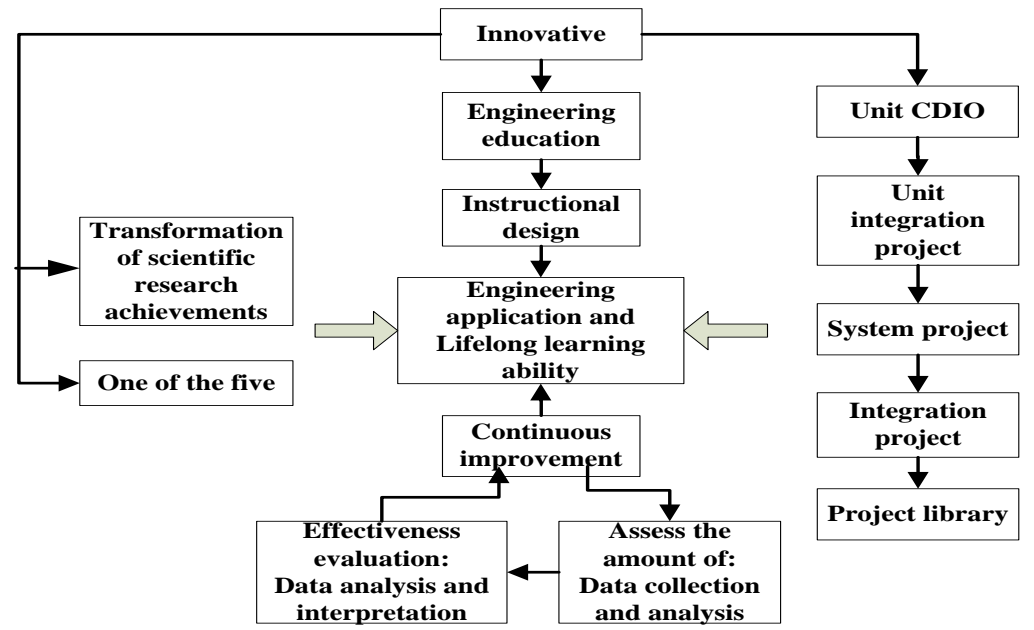

Fig. 1 Industrial automation engineering practice reform measures

CDIO project, from the unit to unit integrated project, project to the system, and finally to the system integration project development. Establish a multi-level, modular network series project library to fully arouse the enthusiasm of teachers, stimulate students' initiative and creativity, to adapt to social development.

This work was supported by the Education Department Project of Jilin Province:(Ji teach high word [2016]32nd) and The Education Department of the Ministry of education higher education professional teaching steer, Project approval number[DQJZW2016002]

Corresponding Author Mi Hongtao 
1.1 Based on the reform model of " $5 \mathrm{~s}$ " and "CDIO" (conceive, design, implementation, and operation) reform mode. From the previous teaching, education, to the comprehensive quality education transformation. Based on "5s+CDIO" concept, cultivating goal set (surface: the conception, design teacher training students' engineering application ability and ability of lifelong learning way and realization method), the implementation process (line: conception and design of the teacher training students' engineering application ability of professional core curriculum group of composition and its connotation and extension) and realization method (points: conception, design teacher training students' engineering application ability of specific knowledge of the course and its implementation scheme), and on the carrier of knowledge, in order to improve the students' engineering application ability and quality for the purpose to design the teaching and learning, we double harvest.

1.2 Scientific research achievements. Pay attention to the scientific research into the teaching material content, design the corresponding teaching facilities, equipment and control system is the same with the engineering practice, provides students with the real engineering practice environment; Through the remote electrical engineering practice teaching platform and network video, to strengthen the resources construction, students' spare time can use the remote practice teaching platform and network video for autonomous learning.

\section{Way to improve the quality of teaching}

Make full use of information technology, to construct a practical engineering in the engineering education ability training in the core group of series course, pay attention to undertake to the student course and organic combination of engineering object ability, to students at the graduation work with the enterprise needs to realize "seamless docking" as the goal. It constitutes the industrial automation engineering practice curriculum system structure adjustment mode as shown in Fig. 2 .

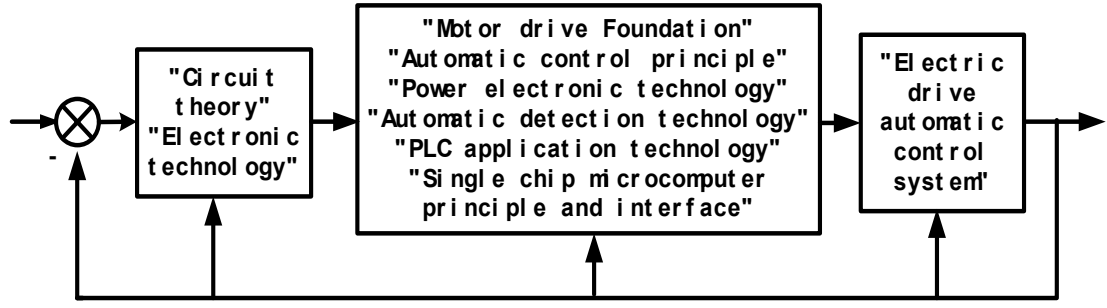

Fig.2 Iindustrial automation engineering practice curriculum system structure adjustment mode

- Building modular, personalized series curriculum group of system. On the theoretical basis for industrial automation engineering practice, industrial automation studio platform is established. Will be associated with the engineering practice in each major course unified, unified planning, construction, causes the student to obtain the solid professional basic knowledge and basic experiment skills, obtain design, simple subject to debug, the ability to analyze and solve problems, to obtain essential basic practice ability of engineering practice.

- Build a combination of theory teaching and practice teaching of the course system. Object to the engineering practice, cross of the curriculum group of the theory teaching and practice teaching organic integration into a system, to establish beneficial to students' autonomous learning, cultivating students' practical experience and engineering application ability. Set up the corresponding experiment, practice, such as practical teaching link, cultivate and improve the students' innovation ability through practice.

\section{The teaching design and teaching}

The goal of teaching design and teaching is the student through the learning process should be the results of the final, should reach from the final results of reverse design. Design ultimately regulations for students of knowledge, ability, or quality need open teaching links, teaching content 
should attach importance to the construction of the module, ability training throughout the whole course system. Evaluation way contains written examination, course design, course thesis, lab reports, studies, etc. Focus on the implementation of inquiry learning, strive to promote learning based on problem, based on the case study, study and so on the many kinds of research learning method based on the project. Inquiry learning is a kind of support knowledge application and innovation, in accordance with law of engineering ability training, is conducive to social ability to ascend, and conform to the overall quality form logic teaching organization form and way of teaching.The key question, independent research and discuss the interaction, improving the core links such as criticism.

3.1 Make consistent with industrial requirements of applied talent training scheme. From the cultivation of ability, and construct project of cultivating ability of decomposing matrix, syllabus, teaching content, teaching and examination methods, etc. Construction of A and B level of professional theory course system (grade A - strong theory, more hours, is A strong ability to learn or continue their education students, class B - applied, fewer class hours, train to solve practical problems and practical ability, meet the demand of employment competitiveness); In practice teaching, and on the basis of the integral characteristic talents cultivation model, invite relevant experts to participate in formulate training plan of the enterprise and the teaching quality evaluation, make the plan more suited to the needs of society.

3.2 According to the thinking of "engineering education" correct self-image. Build system of open laboratory, encouraging students to design experiments independently, provide the conditions for students' innovative experiment; Students' scientific research training program, to create conditions so that the students take part in scientific research and innovation activity early, improve the system of extracurricular teaching innovation and practice of credit replacement;Graduation practice and graduation design and employment closely integrated, graduation design content and engineering combined with practical production, students can complete the graduation design in the enterprise.

\section{The experiment teaching and practical teaching}

Adhere to the "solid foundation, strengthening ability, improve quality, practical" talents cultivation idea of improving the students' ability and quality. Fig. 3 shows the personalized integrated teaching system.

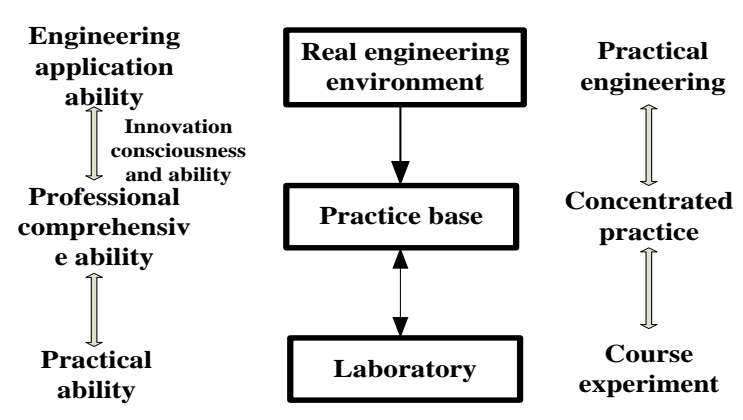

Fig.3 Personalized integrated teaching system 
4.1 Update the experiment teaching content and reforming experiment teaching methods. Optimizing experiment teaching contents, improving teaching methods and teaching means, pay attention to training students' experimental skills and design application ability, improve the comprehensive, designing experiments project scale, the use of modern technology, the traditional practice teaching method, take the theory teaching and practice teaching, combining theory the article moved to the laboratory, talking and practice, the effect of "learning by doing". The theory and experiment on the equally important position, part of the experiment set independent class, a separate test. Outstanding students is the main body, the experiment teaching process training students' experimental ability, research and innovation ability.

4.2 Create a real engineering environment, strengthen the practice teaching. In the school practice base of real engineering case teaching in the environment, cultivating students' engineering consciousness and ability. Let the students experience the real production process by means of Multimedia, shorten the distance teaching and production practice. With practice base for the window, with the scientific research projects as the carrier, the teachers' scientific research and regional industry of actual production, the development of the society, improve teachers' scientific research ability, academic level, make the teaching content dynamic tracking field., facing the $21 \mathrm{st}$ century for teaching and fine materials to use carries on the summary and refining, the scientific research into the teaching, the write to adapt to the training target of the characteristic teaching material.

\section{Conclusion}

The engineering education concept design teaching, the training of engineering ability and lifelong learning ability as the main line of the project as a carrier, with the application of information technology; research and practice of inquiry and study; from unit to unit project, comprehensive project to project, and finally to the development and perfection of the system integration project. The establishment of multi-level, modular network series of projects, in order to fully mobilize the enthusiasm of teachers, to stimulate students' initiative and creativity, to adapt to social development.

\section{References}

[1] Petrova R, Tibrewal A, Sobh T M, An Electronic Web based Assessment System, Journa lof STEM Education, Vol.7, No3, 44-57, 2006.

[2] Basim A-J,Hazim A-A,Curriculum assessment as a ditrect tool in ABET outcomes assessment in a chemical programme. European Journal of Engineering Education, 489 505, 2010.

[3] Wu Z J, Li J Q, Huang C L, adhere to the five attention, promote the five changes, cultivating engineering excellence, higher engineering education research, Vol. 15, No. 5, 2013.

[4] Kong F M, such as the construction of road of the applied university, Peking University press, Beijing, 2006.

[5] Lin J, engineering education accreditation and engineering education reform and development of higher engineering education and research, 2015.

[6] Hong Y G, Cheng D Z generation exhibition, analysis and control of nonlinear system, science press, Beijing, 2005.

[7] Sun Y M, Guo L, about planar affine nonlinear system of global asymptotic controllability, Chinese science (E), Vol. 35, No. 8, 830-839, 2005.

[8] Daizhan Cheng, Controllability of Switched Bilinear Systems, IEEE Trans. on Automatic Control, Vol.50, No.4, 511-515, 2005. 
[9] Daizhan Cheng, R. Ortega, E. Panteley, On port controlled Hamiltonian systems, in Advanced Robust and Adaptive Control -Theory and Applications, (D. Cheng, Y. Sun, T. Shen, H. Ohmori eds), 3-16, , 2005. 